\title{
Proposal for public policies regarding the promotion of online passport scheduling
}

\author{
Luchenciuc Elena-Georgiana \\ luchenciuc.elena@yahoo.com \\ Master of European Administration. Public institutions and policies (Faculty of Law and \\ Administrative Sciences - "Ovidius" University of Constanta, Romania)
}

\section{Volume coordinators}

Prof. univ. dr. habil. Mihaela Rus

"Ovidius" University of Constanta (Faculty of Law and Administrative Sciences)

psiholog_m@yahoo.com

Lect. univ. dr. Mihaela Sandu

"Ovidius" University of Constanta (Faculty of Psychology and Educational Sciences)

mihaela_naidin@yahoo.com

\author{
Asist. univ. dr. Tănase Tasențe \\ "Ovidius" University of Constanta (Faculty of Law and Administrative Sciences) \\ office@pluscommunication.eu
}

\begin{abstract}
About $70 \%$ of Romanians who need to get their passports renewed wait in a queue instead of scheduling an online scheduling. The truth is that many forget that the time of waiting for hours on end in queues has set, and this aspect should disappear from the conception of many people who have experienced hard times many years ago. At a regular queue, a Romanian stays for at least 2 hours if he has not reached among the first persons, which is not at all beneficial for them, but neither for the employees. The objective of the public policy proposal is to promote online scheduling for passports by: reducing queues on passports, reducing the stress of employees who work directly with the public and maintaining a harmonious connection between people and the website https://epasapoarte.ro.
\end{abstract}

Keywords. public policy, passports, online scheduling, Romania 


\section{The institution that initiates public policy \\ The nature of the problem}

\begin{tabular}{|l|l|}
\hline Name of the policy & Pro \\
\hline
\end{tabular}

Purpose

General objective Specific objectives

Government of Romania - Ministry of Internal Affairs, Ministry of Foreign Affairs, General Directorate of Passports

It is known that everyone likes to travel and create memories to carry with them the rest of their lives, but what happens when we face the problem of obtaining a passport? Huge queues, nervous anticipation, annoyance, an acute need to use the toilet and much time wasted which could be reduced if people were well informed. According to a study by Journalists from The Daily Mail, a man spends almost a year of his life waiting. Specifically, there are six months of queuing, 27 days of waiting in stations or bus stations and 20 annoying weeks, waiting on the phone for the other end of the wire to answer a call center operator. About $70 \%$ of Romanians who need to get their passports renewed are queuing instead of scheduling an online scheduling. The truth is that many forget that the time of the queues has set, and this aspect should disappear from the conception of many people who have experienced hard times many years ago. At a regular queue, a Romanian stays for at least 2 hours if he has not reached among the first persons, which is not at all beneficial for them, but neither for the employees.

Proposal for public policies regarding the promotion of online passport scheduling

Because a modern Romania has always been desired, and the country's leadership has made and continues to make all the efforts to solve the most important problems of our society, this time, the Government will find ways to promote the site https://epasapoarte.ro and the idea of online passport scheduling so as to reduce queues and stress for employees who work with the public.

General objective: to promote online scheduling for passports

\section{Specific objectives:}

1 . Reduce queues on passports.

2. Reducing the stress of employees who work directly with the public.

3. Maintaining a harmonious link between people and the website https://epasapoarte.ro

\section{Beneficiaries}

Direct: all the inhabitants of Romania

Indirect: Employees from the General Directorate of Passports

Solution alternatives

no. 1
Conducting an online promotion campaign, for the site https://epasapoarte.ro to a chosen target audience. The campaign will involve images and suggestive texts that will convince the public, specifically those who are passionate about travel or who need to travel abroad for work regurarly, that online scheduling can save them long time at endless queues. An auction will be launched on SEAP to obtain the best services and prices from companies working in the field of

By this way passport self-
scheduling will be promoted online and the queues will be greatly reduced. Although this system has been around for some time, Romanians still prefer to wait many hours in line, which is not productive at all. Thus, the chosen public, not yet informed about this concept, will be able to avoid queues and enjoy a pleasant trip. 
online marketing.

Benefits:

- The target audience will be able to benefit from online scheduling, anytime and anywhere, without having to spend hours in a row in queues.

- The queues will be greatly reduced.

- When the target audience is chosen, no money will be spent on people who are not interested.

- Being already connected to the internet, those who see the campaign will be able to make their scheduling right away, with a simple click, as opposed to indoor and outdoor advertising.

Risks:

- Older people will not be able to adapt to this system.

- There is a risk that the advertisement may not be convincing enough.

- It will not have a large enough impact to considerably reduce queues.

- Many people who might be interested may not spend so much time online. Impact 1

By this way passport selfscheduling will be promoted online and the queues will be greatly reduced. Although this system has been around for some time, Romanians still prefer to wait many hours in line, which is not productive at all. Thus, the chosen public, not yet informed about this concept, will be able to avoid queues and enjoy a pleasant trip. 


\begin{tabular}{|c|c|c|}
\hline $\begin{array}{l}\text { Solution alternatives } \\
\text { no. } 2\end{array}$ & $\begin{array}{l}\text { Indoor and outdoor advertising for } \\
\text { the website of the General } \\
\text { Directorate of Passports, the } \\
\text { section "Online Scheduling" } \\
\text { consisting of posters and banners } \\
\text { of small and large size strategically } \\
\text { located, in bus stations, subways, } \\
\text { buses, highways, etc., so that can } \\
\text { be seen by everyone passing } \\
\text { through those areas. A tender will } \\
\text { be launched on SEAP to obtain the } \\
\text { best services and prices from } \\
\text { companies working in the field of } \\
\text { advertising production. } \\
\text { Benefits: } \\
\text { - More people will be informed } \\
\text { about the concept of online } \\
\text { passport scheduling. } \\
\text { Risks: } \\
\text { - Not all the people who see them } \\
\text { will be interested. } \\
\text { - The costs can be quite high } \\
\text { compared to Variant } 1 \text {. }\end{array}$ & $\begin{array}{l}\text { This would have a much greater } \\
\text { impact on people due to traffic and } \\
\text { "insistence". If a person sees the } \\
\text { information multiple times in } \\
\text { multiple places, he will certainly } \\
\text { remember even if he can later, } \\
\text { those ads will no longer be. This } \\
\text { could even be a long-term } \\
\text { solution. }\end{array}$ \\
\hline & \multicolumn{2}{|c|}{$\begin{array}{l}\text { Participants: } \\
\text { - Representatives of the Ministry of Internal Affairs, the Ministry of } \\
\text { Foreign Affairs, the General Directorate of Passports, Constanţa } \\
\text { County Council, Constanța City Hall } \\
\text { - Citizens of Constanța city } \\
\text { - Representatives of marketing and advertising agencies in the area } \\
\text { Amendments: } \\
\text { During the consultation process, the queue for passports was discussed } \\
\text { especially in the city of Constanța, finding two variants for promoting } \\
\text { online scheduling. The representatives of the Internal and External } \\
\text { Affairs brought about the promotion only at local or national level. On } \\
\text { this issue, the representatives of the Government and the Local } \\
\text { Council chose to campaign first locally to see how it turns out, and } \\
\text { then to extend it to the national level. } 70 \% \text { of citizens of Constanț, } \\
\text { conference participants voted for Variant } 1 \text { due to the fact that they } \\
\text { spend a lot of time on the Internet, showing a great compassion for the } \\
\text { Burnt Forests of Amazon, topical situations, not wishing to consume } \\
\text { excess paper for the promotional materials that they may or may not } \\
\text { reach their goal. Many were interested in the content of the online } \\
\text { campaign. This will be representative of Google and Facebook } \\
\text { campaigns that will consist of banners, images and texts that } \\
\text { encourage people to schedule their online advertising. }\end{array}$} \\
\hline
\end{tabular}


Recommended solution
$85 \%$ of the participants in the event voted for the solution of the number 1 solution, due to the ability to select the public and to spend the financial resources more deliberately. The price for an online campaign is lower than the outdoor and indoor advertising, allowing more campaigns for longer terms. Also, Constanța does not want to use unnecessary paper, being eco-friendly, but there will be other means of promotion (radio, tv) if this solution will not reduce the number of people queuing daily for the passport . 